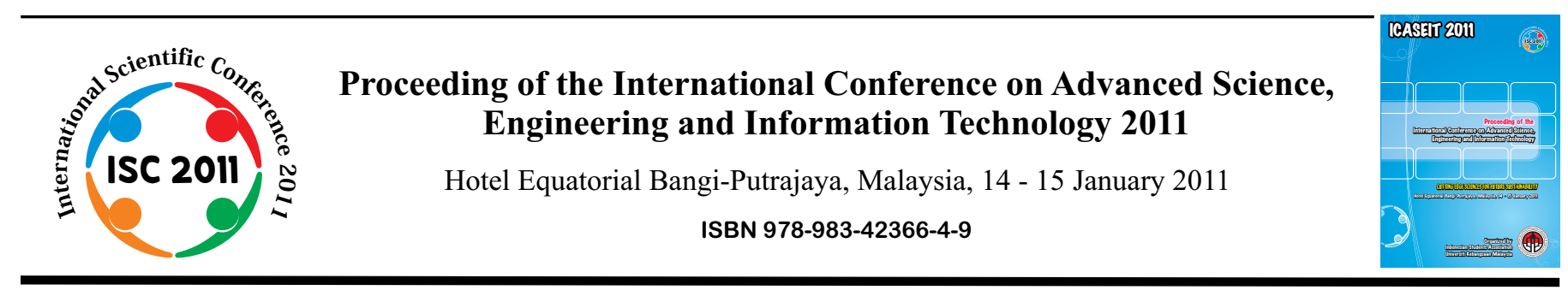

\title{
Sexuality Among Senior High School Students in Papua and West Papua Provinces, Indonesia
}

\author{
Wienta Diarsvitri ${ }^{\# *}$, Iwu Dwisetyani Utomo* \\ \# Dept. of Public Health, Hang Tuah University \\ Jl. Arif Rahman Hakim 150, Surabaya, 60111, Indonesia \\ Tel.:+62315945894,E-mail: wienta_d@yahoo.com \\ *The Australian Demographic and Social Research Institute, the Australian National University \\ Coomb's Building, Fellows Road, Canberra, ACT, 0200, Australia \\ Tel.:+61261250124, E-mail: iwu.utomo@anu.edu.au
}

\begin{abstract}
High risk sexual behaviors have been found in some cultures in Papuan and West Papuan Provinces. Using qualitative and quantitative data, we explore perspectives and experiences on sexuality, alcohol use, contraceptive use, unintended pregnancy and symptoms of sexually transmitted diseases among 1,082 Year 11 students from 16 senior high schools in Papua and West Papua Provinces, Indonesia. The data were based on the 2009 Reducing the Risk of HIV/AIDS Intervention Trial for Young Papuan Study. Our results indicated that around $\mathbf{3 8 . 3 \%}$ of students reported having sexual intercourse. It was also found the relationship between alcohol use and premarital sexual intercourse. The contraceptive use was very low, $31.8 \%$ of female students who had sexual intercourse experienced unintended pregnancy, and majority of students who reported experiencing symptoms of sexually transmitted diseases also reported having sexual intercourse.
\end{abstract}

Keywords - Young people, sexuality, premarital sex.

\section{INTRODUCTION}

Sexuality and sexual practices are influenced by different cultural and social environment. ${ }^{[1,2]}$ Previous studies discovered high risk sexual behaviors among people in Papua that may pose them to HIV/AIDS infection and transmission, such as extramarital sex, multiple sex partners, sex at young age, sequential sex, secret sex and youth sex party, ${ }^{[3,4,5]}$ as well as the use of discarded syringe to inject tree sap for penis enhancement, ${ }^{[6]}$ and the use of wrap leaves, oil from dried leech and inserting metal for penile implantation. ${ }^{[7]}$

Premarital sex among young Indonesian in different areas is rising, ${ }^{[8,9,10]}$ and it is soaring and becoming more common in the two most eastern provinces in Indonesia, Papua and West Papua Provinces. ${ }^{[3,4,5,7,11]}$

The estimated number of people living with HIV in Indonesia has rocketed since 1998, and the highest prevalence of HIV/AIDS (2.4\%) was found in Papua and West Papua provinces. ${ }^{[12,13]}$ As of 2007 , the majority (54.3\%) of HIV/AIDS cases in Papua Province were among population aged 20-29 years and the cases among population aged 15-19 years were ranked the forth, in which heterosexual intercourse being the most mode of transmission. $^{[14]}$

\section{METHODS}

This paper focuses on the results from the preintervention questionnaire from the 2009 Reducing the Risk of HIV/AIDS Intervention Trial for Young Papuan study that was carried out in February until June 2009. Sixteen senior high schools were randomly chosen from 89 available senior high schools in Jayapura City and Jayapura Regency, Papua Province; also Manokwari Regency and Sorong City, West Papua Province. 1,082 unmarried Year 11 students were enrolled.

All questions were translated in both Indonesian and Papuan language. The recruitment was based on the sample size formula for a cluster randomized trial provided by Donner. ${ }^{[15]}$ In addition to the survey, a qualitative study was conducted. In-depth interviews $(\mathrm{N}=40)$ were conducted among senior high school teachers and students, staff of education office, staff of Non Governmental Organization, doctors, midwives, nurses, youth street sex workers and 
indigenous tribe leaders.

The completed questionnaires were put in the sealed envelopes by the students themselves and handed over to the research team. The research team in the study consisted of nine medical doctors and twelve staff of Non Governmental Organization that works on HIV/AIDS prevention.

All analyses were performed using SPSS 17.0 (SPSS Inc., Chicago, Illinois, USA).

This study has been approved under a full ethical review by the Australian National University Human Research Ethics Committee on 30 January 2009; a written permission from Directorate General of Nation Unity and Politics, Ministry of Internal Affairs Republic of Indonesia on 13 February 2009; written permissions from the provincial, regency and city level governments; also written permission from the school level and individual consents.

\section{FINDINGS}

Of the total 1,082 students, $50.5 \%$ (546) were females, $49.5 \%$ (536) were males. The mean age was $18.9(\mathrm{SD}=1.2)$, and students' age ranged from 16.8 to 21.6 years. All students were unmarried at the time of research, however many students in private general schools did not pass to the next grade several times, so they were older than other fellow students from government schools. Fifty nine percent (637) of students were Papuan, 35.3\% (382) were Non Papuan and $5.8 \%$ (63) were mixed ethnicity. $95.7 \%$ of students (1036) had heterosexual orientation, 3.4\% (37) were bisexual, $0.7 \%$ (eight) were homosexual, and $0.1 \%$ (one) was transgender. The students came from government general schools were $25.9 \%$ (280), private general schools were $49.2 \%$ (532), and government vocational schools were $25.0 \%(270)$.

Thirty two percent (351) of students reported having tried alcohol and 4.3\% (46) reported having ever tried drugs. Seventeen percent (181) reported currently drinking alcohol and $1.8 \%$ (19) reported currently using drugs.

Thirty eight percent of (414) students reported having sexual intercourse (anal or vaginal intercourse); whereas $26.5 \%$ (287) of students reported having some sexual experiences (kissing and petting but no intercourse); 33.5\% (362) of students reported never having any sexual experience, and $19(1.8 \%)$ did not specify their sexual experience.

There was a strong association between gender and sexual experience; with $47.9 \%$ of male students reported having had sexual intercourse, compared with only $28.8 \%$ of female students $(\mathrm{p}<0.001)$. There was a strong association between current alcohol use and sexual experience, with $86.7 \%$ of respondents who reported currently drinking alcohol also reported having had sexual intercourse, compared with only $28.6 \%$ of respondents who reported not currently drinking alcohol $(\mathrm{p}<0.001)$.

Of the total 414 students who reported having had sexual intercourse, $60.1 \%$ of them reported having had it at the age of 15 years or older (Table 2), $30.2 \%$ of them had it when they were between $13-14$ years, and $6.5 \%$ of them had it when they were less than 12 years of age and majority (74.1\%) were Papuan students. Seventy two percent of students had their first sexual intercourse with their friends, $8.9 \%$ with sex workers and $11.8 \%$ with others (including relatives). A larger part of those who had their first sexual intercourse with sex workers and others were Papuan. The most cited reason for having the first sexual intercourse was sexual drive (26.6\%), curiosity (13.8\%), expressing love (13.3\%), other (watching porn movie, don't know, ease the stress) $(10.6 \%)$, force $(10.4 \%)$, drunk $(6.8 \%)$, peer pressure $(6.0 \%)$ and afraid of break up (4.8\%).

The in-depth interview among students supported the above finding about premarital sex among students. A 17year old male student from a private school in Jayapura City stated:

"I have some male friends in other school who have ulcers in their genital. They are about twenty years old now. They began to have a sexual intercourse at around 18 years old. They have ever been to Tanjung ( a legal brothel in Jayapura Regency) many times, but after they got the disease they have regretted it. They want to seek help, but they did not know (where they should go)."

A 20-year old female student from a private school in Jayapura Regency expressed:

"A nurse have diagnosed me with kencing nanah (gonorrhea). I have ever had sexual intercourse, many times, when I was in my village. I didn't know anything at that time. The first time I had it when I was 12 years old, with my older relative. He forced me to do it. After that I had it several times with him and my boy friend. I am currently in senior high school, I read about sexually transmitted diseases from my science book, I am afraid about it."

A greater part of students (73.9\%) who have ever had sexual intercourse reported having one sexual partner, $21.7 \%$ having $2-5$ sexual partners, and $4.3 \%$ having six or more sexual partners. This is alarming, even more because $14.9 \%$ of students having $2-5$ sexual partners and $1.9 \%$ had six or more sexual partners in the last two months, despite the fact that majority of students (68.4\%) reported having one sexual partner in the last two months. A larger part of respondents who had six or more partners were Papuan, although the analyses of sexual partners among different ethnicity were not significant.

Fifty-nine percent of students who reported having had sexual intercourse also reported never used condom, only $1.2 \%$ reported always used condom in the last two months and $4.6 \%$ reported using condom in the last sexual intercourse.

Furthermore, $31.8 \%$ of female students who reported ever having sexual intercourse also reported ever having unintended pregnancy. Further, $86.0 \%$ of female students who reported ever been pregnant also reported experiencing unsafe abortion by trying to terminate their pregnancy by themselves $(74.4 \%)$. 
Based on the interview with 24 senior high school teachers, it was found that there were many sexuality problems in schools, such as distributing pornographic photos or clip through cellular phone, sexual relationship and unintended pregnancy. Almost every year there are dropouts in some schools due to unintended pregnancy. It was written in the school regulation that female students who are pregnant have to resign from school, although there is certain school that would accommodates those who wants to return to school after delivery.

A 47-year old male biology teacher at a private school in Sorong City stated:

"Pregnancy incidents always happen here every year.

We often say that we have so many grandchildren.

Some students said they have abortion, but some gave their babies to their parents. The babies become children of their parents. After that they return to school. Their parents don't want them to get married because they want their children to finish school."

A 40-year old male private senior high school principal who was also a physical education teacher in Sorong City stated:

"Every year I say I get grandchildren. A lot of unintended pregnancies have happened here. This school was established to help the needy, those who were dropped out from other schools. So, actually this school is a garage for human. So, most of the students who cannot go to public school will come here. They are accepted here. Usually we have sent home female students who were pregnant. However, after they gave birth, they usually reported to me and asked whether they could go to school again. I feel pity for them. If we don't accept them, they have no where to continue their education. So, I told them the important thing was that you understood your mistake that has been happened and you could study seriously. I see some teenagers become good and some become government employees."

Additionally, there is a strong association between experiencing symptoms of sexually transmitted diseases (vaginal discharge, ulcers in genitals and painful discharge when urinating) with sexual experience $(\mathrm{p}<0.001)$.

\section{DISCUSSION}

Premarital sex has been known to be associated with the use of alcohol and drug. ${ }^{[16,17]}$ The substance use also associated with multiple sexual partner ${ }^{[16,18]}$ and early childbearing. ${ }^{[18,19]}$ Two possible explanations that may explain the association between substance use and risky sexual behavior are: there is a general tendency to take risks when environment supports such behavior; also drug and alcohol lessen both inhibitions and rational decision-making, thereby increasing the likelihood of unprotected sex. ${ }^{[20]}$
Our study found a very low condom use, only $4.6 \%$ students reported using condom in the last sexual intercourse. Djoht et al (2005) found that less than $40 \%$ of sexually active young people in Papua Province have ever used condom, while BPS-Statistics Indonesia and $\mathrm{MoH}$ (2007) found a much lower percentage $(2.8 \%)$.

The 2007 national basic health research that was carried out among general population in 33 provinces revealed $0.3 \%$ of young people aged $10-14$ years and $3.5 \%$ of young people aged 15-24 years were currently drinking alcohol, and the percentage in Papua Province was higher than the national average. The same research that was carried out in 20 regencies and cities in Papua Province found $50.0 \%$ of young people aged $10-14$ years and $66.5 \%$ of young people aged 15-24 years were currently drinking alcohol. ${ }^{[21,22]}$

CHR-UI (2003) found that dating and having sexual intercourse were becoming more common among Papuan youth. Some expressions during a focus group discussion were:

"Some young people use motorbike for sightseeing. Walking together by holding each other hands, expressing sexual intimacy in public are quite common. After dark dating couples will try to find a secret place. Some will go to a hotel or have sex in bushes."

"Here if we have a girl friend and never have sex, they will say that we are not a man. This is especially among the indigenous. The immigrant is not like that."

In a focus group discussion a parent cited ${ }^{[7]}$ :

"Nowadays, we, as parents don't know whether our children are dating. In the morning and afternoon they look like that they don't know each other, but at night they are like husband and wife. They go to school (school is dark at night, so it is used by young people for a dating place) or they go to the harbor."

Changing sexual practices into more permissive in many Indonesian cities led to increasing numbers of young, unmarried women who become pregnant choosing abortion. ${ }^{23}$ Utomo et al. (2001) estimated there were around two million abortion cases per year in Indonesia and approximately 30 percent of them were for adolescents. Our study revealed majority of female students who reported having unintended pregnancy also reported having unsafe abortion.

Exposure to the risk of unprotected sex, pregnancy and sexually transmitted diseases, including HIV/AIDS, begins in the teenage years when young people engaged in their premarital sex, ${ }^{[13,19,25,26,27]}$ and this will lead to dropping out of school earlier and reduction in future life opportunities. ${ }^{[28,29]}$

Future research should focus on the risk and protective factors of young people sexual behavior, as well as program intervention trial to reduce the risk of HIV/AIDS in both provinces. ${ }^{[30]}$ Caldwell emphasized the importance of understanding the relationship between culture and risk. ${ }^{[31]}$ It is a necessity to address cultural values in any intervention that aims at reducing the risk of HIV/AIDS, so that the 
program will have an effect. In the perspective of health transition theory, an effect is achieved when there is a changing of cultural values in order to change sexual behavior, which will in turn reduce the risk of infection. ${ }^{[32]}$

\section{CONCLUSIONS}

Our findings found many high risk sexual behaviors among Year 11 students with earlier age of sexual intercourse, exposed to sex workers, having multiple partners, unprotected sex, unintended pregnancy, unsafe abortion and symptoms of sexually transmitted diseases have put them into high risk group for HIV/AIDS infection and transmission.

To reduce the risk of HIV/AIDS that has been soared in Papua and West Papua Provinces, as well as unprotected sex, pregnancy and childbearing, a careful and committed endeavor must be carried out. Blum and Mmari (2005) underlined the importance of implementation of both programs and policies. ${ }^{31}$ Four program approaches that have been suggested by Kirby (2002) were comprehensive sex and HIV education programs that cover both abstinence and condoms or contraception; improvement of protocols for health clinic and supported activities; availability of service learning programs; and the children's aid society programs, that provide multiple services for youth, parents and community. ${ }^{32}$

\section{ACKNOWLEDGMENT}

This study was funded by the Australian Demographic and Social Research Institute, the Australian National University. We are thankful to all research team in Papua and West Papua Provinces.

\section{REFERENCES}

[1] Kazaura M.R., M.C. Masatu. 2009. Sexual practices among unmarried adolescents in Tanzania. Bio Med Central Public Health 9: 372-377.

[2] Lydiè N., N.J. Robinson, B. Ferry, E. Akam, M. De Lonzien, L. Zekeng, S. Abega. 2004. Adolescent sexuality and the HIV epidemic in Yaoundé, Cameroon. Journal of Biosocial Science 36: 597-616.

[3] Butt, L., G. Numbery, J. Morin. 2002. Preventing AIDS in Papua. Revised research report. (http://www.freewestpapua.org/docs/butt2002-prevent.pdf) (Accessed June 12, 2010)

[4] Djoht, D.R., Marsum, H.Y. Lekito, I. Peyon, N. Fakdawer. 2005. Sebuah survey pada kaum muda di luar sekolah usia 10-24 tahun di Papua, Indonesia, 2005. Pengembangan edukasi sebaya guna penurunan penularan HIV/AIDS pada kaum muda di Propinsi Papua. (A report of peer education development to reduce HIV/AIDS transmission among young people outside school aged 10-24 years in Papua Province). Jayapura: Pusat Studi Kependudukan, Universitas Cendrawasih dan UNICEF Indonesia.

[5] Centre for Health Research University of Indonesia (CHR-UI). 2003a. A survey of teenagers in Papua, Indonesia, 2003. Qualitative baseline data collection for intervention aimed at reducing HIV vulnerability of young people in Papua Province. Jakarta: Center for Health Research, University of Indonesia.

[6] Hull, T.H. and M. Budiharsana. 2001. Male circumcision and penis enhancement in Southeast Asia: Matters of pain and pleasure. Reproductive Health Matters 9: 60-67.

[7] Djoht, D.R. 2005. Sebuah survey pada kaum muda di luar sekolah usia 10-24 tahun di Papua, Indonesia, 2005. Laporan kualitatif.
Pengembangan edukasi sebaya guna penurunan penularan HIV/AIDS pada kaum muda di Propinsi Papua. (Qualitative report of peer education development to reduce HIV/AIDS transmission among young people outside school aged 10-24 years in Papua Province). Jayapura: Pusat Studi Kependudukan, Universitas Cendrawasih dan UNICEF Indonesia.

[8] Singarimbun, M. 1991. Norma-norma dan perilaku seks remaja (Norms and sexual behaviors of teenagers). Populasi. Buletin Penelitian Kebijaksanaan Kependudukan 2: 11-24.

[9] Utomo, I.D. 1997. Sexual attitudes and behaviour of middle-class young people in Jakarta, $\mathrm{PhD}$ diss., The Australian National University.

[10] Situmorang, A. 2001. Adolescent Reproductive Health And Premarital Sex in Medan. PhD diss., The Australian National University.

[11] Centre for Health Research University of Indonesia (CHR-UI). 2003b. A survey of teenagers in Papua, Indonesia, 2003. Quantitative baseline data collection for intervention aimed at reducing HIV vulnerability of young people in Papua Province. Jakarta: Center for Health Research, University of Indonesia.

[12] Joint United Nations Programme on HIV/AIDS (UNAIDS). 2008 2008 Report on the global AIDS epidemic. Geneva: UNAIDS http://www.unaids.org/en/KnowledgeCentre/HIVData/GlobalReport/ 2008/2008_Global_report.asp (Accessed May 10, 2010)

[13] Badan Pusat Statistik (BPS-Statistics Indonesia) and the Ministry of Health Republic of Indonesia (MoH). 2007. Risk behaviour and HIV prevalence in Tanah Papua 2006. Results of the integrated biobehavioural surveillance survey (IBBS) 2006 in Tanah Papua.

[14] Health office of Papua Province. 2008. Report on the cumulative cases of HIV/AIDS in Papua Province 2008.

[15] Donner, A. 1998. Some aspects of the design and analysis of cluster randomization trials. Journal of the Royal Statistical Society. Series C (Applied Statistics) 47(1):95-113.

[16] Magnani, R.J., A.M. Karim, L.A. Weiss, K.C. Bond, M. Lemba, G.T. Morgan. 2002. Reproductive health risk and protective factors among youth in Lusaka, Zambia. Journal of Adolescent Health 30:76-86.

[17] Podhisita C., P. Xenos, A. Varangrat. 2001. The risk of premarital sex among young Thai youth: individual and family influences. EastWest Center Working Papers, No. 108-5.

[18] Stanton B.F., A.M. Fitzgerald, X. Li, H. Shipena, I.B. Ricardo, J.S Galbraith, N. Terreri, J. Strijdom, V.H. Ndlovu, J. Kahihuata. 1999. HIV risk behaviors, intentions, and perceptions among Namibian youth as assessed by a theory-based questionnaire. AIDS education and prevention 11:132-149.

[19] Lee, M.C., S.H. Lee, and M.C. Chou. 2001. Association of risktaking behaviors with adolescent childbearing. Journal of Formosan Medical Association 100:533-538.

[20] Kirby, D. 2001. Emerging answers: Research findings on programs to reduce sexual risk-taking and teen pregnancy. Washington, DC: National Campaign to Prevent Teen Pregnancy.

[21] Badan Penelitian dan Pengembangan Kesehatan Departemen Kesehatan Republik Indonesia. (National Institute of Health Research and Development, Department of Health Republic of Indonesia). 2008a. Laporan Hasil Riskesdas Nasional. (Report of national basic health research). Jakarta.

[22] Badan Penelitian dan Pengembangan Kesehatan Departemen Kesehatan Republik Indonesia. (National Institute of Health Research and Development, Department of Health Republic of Indonesia). 2008b. Laporan Riskesdas Provinsi Papua. (Report of basic health research of Papua Province). Jakarta.

[23] Hull, T.H., S.W. Sarwono, N. Widyantoro. 1993. Induced abortion in Indonesia. Studies in Family Planning 24: 241-251.

[24] Utomo, B., N.G. Dharmaputra, A. Habjah, Irwanto, S. Sitohang., D.N. Wirawan, K.T. Widarsa, K. Gunung, G.M. Sumantera, K.N. Siregar., et al. 2001. The incidence of abortion in Indonesia: Result of a community-based survey in 10 major cities and 6 districts. Jakarta: Center for Health Research University of Indonesia.

[25] Blanc A.K., A.A. Way. 1998. Sexual behavior and contraceptive knowledge and use among adolescent in developing countries. Studies in Family Planning 29: 106-116.

[26] Singh S. 1998. Adolescent childbearing in developing countries: A global review. Studies in Family Planning 29:117-136.

[27] Shittu L.A.J., M.P. Zachariah, G. Ajayi, J.A. Oguntola, M.C. Izegbu, 
O.A. Ashiru. 2007. The negative impacts of adolescent sexuality problems among secondary school students in Oworonshoki Lagos. Scientific Research and Essay 2:023-028.

[28] Lloyd, C.B., B.S. Mensch. 2006. Marriage and childbirth as factors in school exit: An analysis of DHS data from Sub-Saharan Africa. Policy Research Division Working Paper No. 219. New York: Population Counci

[29] Biddlecom Biddlecom A., R. Gregory, C.B. Lloyd, B.S. Mensch. 2008. Associations between premaritals ex and leaving school in four Sub-Saharan African countries. Studies in Family Planning 39:337350.

[30] Caldwell, J. 1999. Reasons for limited sexual behavioral change in the sub-Saharan African AIDS epidemic. In Resistances to behavioral change to reduce HIV/AIDS infection, ed. J.C. Caldwell, P. Caldwell, J. Anarfi, K. Awusabo-Asare, J. Ntozi, I.O. Orubuloye, J. Marck, W. Cosford, R. Colombo, E. Hollings, 241-256. Canberra: Australian National University.

[31] Blum, R.W., K.N. Mmari. 2005. Risk and Protective Factors Affecting Adolescent Reproductive Health in Developing Countries. Department of Population and Family Health Sciences Johns Hopkins Bloomberg School of Public Health. Baltimore: World Health Organization and John Hopkins Bloomberg School of Public Health.

[32] Kirby D. 2002. Effective approaches to reducing adolescent unprotected sex, pregnancy and childbearing. The Journal of Sex Research 